\title{
Dynamic Sustainable Success Prediction Model for Infrastructure Projects: A Rough Set Based Fuzzy Inference System
}

\begin{abstract}
Purpose

Successful implementation of infrastructure projects has been a controversial issue in recent years, particularly in developing countries. In this study, an attempt is made to propose a Decision Support System (DSS) for the evaluation and prediction of project success while considering sustainability criteria.

\section{Design/methodology/approach}

To predict sustainable success factor, the study first developed its Sustainable Success Factors (SSF) and Sustainable Success Criteria (SSC). These then formed a decision table. A Rough Set Theory (RST) was then implemented for rules generation. The decision table was used as the input for the rough set, which returned a set of rules as the output. The generated rule sets were then filtered in Fuzzy Inference System (FIS), before serving as the basis for the DSS. The developed prediction tool was tested and validated by applying data from a real infrastructure project.

\section{Findings}

The results show that the developed rough set -fuzzy method has strong ability in evaluation and prediction of the project success. Hence, the efficacy of the DSS is greatly related to the rule-based system, which applies RST to generate the rules and the result of the FIS was found to be valid via running a case study.

\section{Originality/value}

Use of DSS for predicting the sustainable success of the construction projects is gaining progressive interest. Integration of RST and FIS has also been advocated by the seminal literature in terms of developing robust rulesets for impeccable prediction. However, there is no preceding study adopting this integration for predicting project success from the sustainability perspective. The developed system in this study can serve as a tool to assist the 
decision-makers to dynamically evaluate and predict the success of their own projects based on different sustainability criteria throughout the project life cycle.

Key Words: Infrastructure projects, rough set theory, sustainability, project success, the fuzzy inference system

\section{Introduction}

Over the last decade, there has been a growing emphasis on the successful implementation of construction projects (Pour Rahimian et al., 2019; Pour Rahimian et al., 2020; Zarghami et al., 2018). The primary challenge has always been the ambiguities associated with assessing and anticipating success on such projects, since predicting several probable issues from a vast set of data is more problematic (Cheng et al., 2013). However, there is still no consensus between project management researchers as to how project success is measured or predicted (Elbarkouky, 2012a; Pinto and Slevin, 1988) since the critical characteristic of construction projects is their unpredictability in comparison with rather static production industries (Loosemore et al., 2003).

Traditional approaches addressing project success are restricted to deliver projects on cost, time and quality. Since construction investment mainly focuses on economic benefits (and these kinds of projects have mostly detrimental impacts on social and environmental dimensions) considering sustainable development would be a necessity in presenting a comprehensive success prediction model (Kibert, 2016; Kolo et al., 2014), despite the shortage of relevant studies within the extant literature. On the other hand, accomplishing construction projects successfully requires continuous monitoring and control by construction managers. The project manager and project team have to make judgment during project execution about whether the project will be successful or not (Ding and Banihashemi, 2017).

Therefore, this study aimed at designing a dynamic Decision Support System (DSS) that is capable of prediction of project success from the sustainability perspective throughout the project lifecycle. The 
developed DSS model employs Rough Set Theory (RST) (Pawlak, 1982) in conjunction with the Fuzzy Inference System (FIS) to help the project develop robust rulesets for impeccable prediction.

The remainder of the paper is organised as bellow. The following section, "Literature Review", investigates the concepts of success in construction projects. Research Methodology section explains and presents data collection and demonstrates the review of RST and fuzzy logic. The Results and Analysis section outlines how the rough-fuzzy based prediction model was developed, tested and validated through an illustrative example. The article concludes with practical recommendations to use of this model in the future works.

\section{Literature review}

\subsection{Project Success}

The definition of project success has undergone some transformations over the years. Traditionally, a construction project was deemed successful when it met criteria related to time, cost, and quality (Atkinson, 1999). As pointed out by Belassi and Tukel (1996), research on project success needs to distinguish success factors and success criteria. Cooke-Davies (2002) highlighted the difference between the success criteria and success factors. Project success factors or Critical Success Factors (CSFs) are independent variables of a project, which contribute to achieving success in a project (Müller and Turner, 2007; Rockart, 1982).

Project success criteria are dependent variables by which the success or failure of a project will be

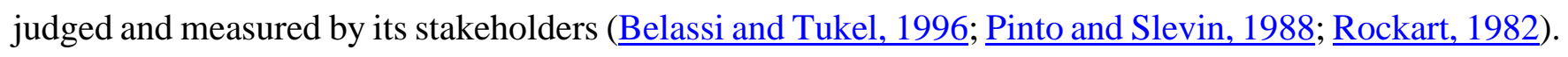
Factors constituting the success criteria are commonly referred to as the key performance indicators (KPIs). The difference between KPIs and CSFs needs to be taken into consideration. Cox et al. (2003) argued that CSFs are the efforts made - or strategies adopted - to achieve the success of a project. 
Whereas, KPIs are the compilations of data measures used to access the performance of the construction project. In other words, the KPIs are essential for comparing effectiveness, efficiency and quality of the actual and estimated performances in of both workmanship and product.

Literature regarding the area of project success reveals that various authors have identified many success determinants, either from experience or research. Westerveld (2003) revealed that along with the conventional measures of cost, time, quality, and scope, there are other five KPIs that are used most frequently: 1) client's appreciation, 2) project personnel appreciation, 3) users' appreciation, 4) contracting partners' appreciation and 5) stakeholders' appreciation. Belout and Gauvreau (2004) emphasised on the project team's ability to manage project risks and to resolve the problems encountered on the project to evaluate the project success. In a study by Cserhati and Szabo (2014), analysis of correlations revealed that relationship-oriented success factors, such as communication, co-operation and project leadership, play a vital role in the successful implementation of projects.

Infrastructure projects require large budgets and a prolonged schedule, and they involve many complicated procedures. Several attempts have been made to address project success in these projects. Brundtland et al. (1987) identified success factors for large projects using factor analysis method. These factors were grouped into four major categories: 1) incompetent designers and contractors, 2) poor estimation and change management, 3) social and technological issues, and 4) improper techniques and tools. In another research, Ogunlana (2010) argued that these traditional criteria for success were not sufficient to determine whether or not the project was successful, and quantitative as well as qualitative criteria such as environmental regulations, building performance, and client satisfaction should also be considered. 


\subsection{Sustainable success indicators}

Al-Tmeemy et al. (2011), measured the success of building projects for sustainable social housing in Nigeria. They identified several critical success factors influencing sustainable housing. In a more recent study, Krajangsri and Pongpeng (2016) addressed the impacts of sustainable infrastructure assessments on construction project success using Structural Equation Modelling (SEM). In their research, construction project success was measured using six criteria: time, cost, quality, client satisfaction, safety, and environment. Banihashemi et al. (2017) looked at the CSFs affecting the integration of sustainability into project management practices of construction projects in developing countries. Having innovation diffusion theory as the theoretical point of departure, they identified 59 CSFs pertaining to the triple bottom line of sustainability (environmental, social and economic). A number of most related studies with different perspectives toward success criteria and success factors are summarised in Table 1 and Table 2.

Table 1. Summary of available previous studies on sustainable success factors

Table 2. Summary of available previous studies on sustainable success criteria

\subsection{Project success prediction}

In recent years, there have been many studies proposing different prediction models for project success. Kim et al. (2009) developed an SEM to predict the project success of uncertain international construction projects. In their study, through a comparative analysis of SEM with multiple regression analysis and artificial neural network, SEM showed a more accurate prediction of performance. Moreover, Cheng et al. (2010) proposed an Evolutionary Support Vector Machine Inference Model (ESIM) to the dynamic prediction of project success. Their model integrated the process of continuous assessment of project performance (CAPP) to select factors that influence project success dynamically. Furthermore, Cheng et al. (2013) proposed an evolutionary Gaussian process inference model for the dynamic success 
prediction. They built an Evolutionary Gaussian Process Inference Model (EGPIM), using a Gaussian process, along with Bayesian inference and particle swarm optimisation. The model was trained using the EGPIM and proved quite precise at predicting the success of a project and had exceptional performance in time-series applications. Besides, one of the outstanding models presented to predict construction cost and schedule success using artificial neural networks and support vector machines classification proposed by Wang et al. (2012). Their findings showed that early planning status can be efficiently adapted to predict project success and the proposed Artificial Intelligence (AI) models can deliver acceptable prediction results.

From a slightly different point of view, Khosravi and Afshari (2011) developed a success measurement model for construction projects to establish a benchmark for measuring future construction projects and comparing the success of finished projects. The implemented methodology was a two-round Delphi study complemented with a questionnaire survey. Khang and Moe (2008) also presented a new conceptual framework for international development project success. They delineated a link between success factors and criteria in order to base their model for assessing the project status and forecasting the results of project throughout the life cycle. Abd-Hamid et al. (2015) also identified success predictors, and presented a conceptual framework for formulating the success of entrepreneurs in the construction industry. Kim et al. (2009) developed an analytic network process model to predict the Performance of International Construction Joint Ventures (ICJV). Within their study, the relationship between the important determinants of ICJV success was found. Eventually, they tested the model based on the eight real construction projects and obtained satisfactory results. 


\section{Research methodology}

\subsection{Sustainable success measurement}

In developing sustainable success measurement criteria, this study followed Akbari et al. (2018) who established a list of sustainable success indicators, namely Sustainable Success Factors (SSF) and Sustainable Success Criteria (SSC). They designed a questionnaire survey using 20 SSFs and 15 SSCs, being classified into the triple bottom line of economic, social and environmental groups. Finally, they selected 11 factors and 9 criteria from these three groups, as mentioned in the following paragraphs.

The identified SSFs: Time management (F1), Cost management (F2), Quality management (F3), Risk management (F5), Leadership (F12), Competent project team (F13), Motivation (F14), Teamwork (F10), Attempt to preserve environment /environmental protection (F15), Waste management (F16) and Environment protection measures in project design (F18).

The selected SSCs: Project completion within time (C1), Project completion within budget (C2),

Project quality (C3), Employer satisfaction/Client satisfaction/owner satisfaction (C6), Provision of employment opportunities (C8), Overall health and safety measures (C9), Environmental degradation (C11), Energy consumption (C15) and Effect on air and land pollution (C13).

Next, to identifying sustainable success indicators, the AHP approach was utilised to quantify and calculate success based on the data collected from 20 experts. With respect to the weight factors, the success indices of the three categories of sustainability were calculated using the following equations:

$\mathrm{ECSI}=0.31 \mathrm{C} 3+0.38 \mathrm{C} 1+0.31 \mathrm{C} 2$

SOSI $=0.43 \mathrm{C} 11+0.34 \mathrm{C} 15+0.23 \mathrm{C} 13$

ENSI $=0.48 \mathrm{C} 6+0.37 \mathrm{C} 9+0.15 \mathrm{C} 8$

Where: 
ECSI=Economical Success Index, SOSI=Social Success Index, ENSI=Environmental Success Index. It is noteworthy that the economic category is the most important one, with $62 \%$ of the weighting. It is two to four times greater than that of the social category (24\%) and environmental category (14\%), respectively.

Therefore, it was concluded that most attention should be paid to the economic point of view, whilst the social and environmental aspects should be taken into account as well. Moreover, sustainable success index is calculated as follows:

$\mathrm{SSI}=0.62 \mathrm{ECEI}+0.24 \mathrm{SOSI}+0.14 \mathrm{ENSI}$

Where: SSI=Sustainable Success Index

Subsequently, respondents were asked to give a score based on the status of the selected success factors and criteria in the aforementioned projects which they were responsible to them. These numbers were between 1 and 5 where: 1 represents "very bad", 2 - "Slightly bad", 3 - "Moderate", 4 - "good", and 5 “excellent". Finally, based on Equ.4, the sustainable success index of these projects had been calculated and a decision table used in RST was created.

\subsection{Methodological Review}

Recently, AI has been deployed as a powerful tool to support decision making in construction projects (Martínez Magaña and Fernández-Rodríguez, 2015). The machine learning techniques such as have been used for modelling building energy-related neural networks, support vector machine and decision trees

(Seyedzadeh et al., 2019). These accurate and fast predictors enable exploration of a vast combination of building characteristics both in the design stage and retrofit planning (Seyedzadeh et al., 2018). To deal with the uncertainty in building and construction data (and weather) rough set was coupled with machine 
learning techniques (Shi and Li, 2008). Fuzzy logic another AI method has also received significant attention in this area due to handling subjective arising during the construction process (Lam et al., 2007).

Fuzzy logic provides an accurate approach for dealing with vagueness. Their rule-based nature allows the use of information expressed in the form of natural language statements. Fuzzy inference is an expert system that interprets the values in the input vector, and based on some set of if-then rules, assigns values to the output vector.

RST does not need a membership function and compared to other statistical methods, and it does not require a large number of data points to find a rule (Pheng and Hongbin, 2006). The most important advantage of this theory is its capability of estimating the significance of specific attributes (Liu and Yu, 2009). The fundamental concept of the rough set algorithm for the proposed application is described in the following paragraphs.

\section{Definition 1: Information Systems}

Information systems are the set of objects described by their attributes and attribute values. The information system is defined as follows:

$$
I S=(U, A)
$$

Where $\mathrm{U}$ is the universe, a finite non-empty set of objects, $U=\left\{x_{1}, x_{2}, \ldots, x_{m}\right\}$, and $\mathrm{A}$ is the set of attributes. Each attribute $a \in A$ (attribute $a$, belonging to the considered set of attributes A) defines an information function:

$$
f_{a}: U \rightarrow V_{a}
$$

Where $V_{a}$ is the set of values of $a$, called the domain of attribute $a$. In all attributes, there are decision attributes and condition attributes.

\section{Definition 2: Core and reduct of attributes}


The concepts of core and reduct are two fundamental concepts of the rough sets theory. A reduct is the minimal subset of attributes that enables the same classification of elements of the universe as the entire set of attributes. In other words, properties that do not belong to a reduct are superfluous with regard to classification of elements of the universe. The core is the necessary element for rules and is the common portion of all reducts. Let B be a subset of A. The core of B is the set of all indispensable attributes of B. The following is an important property, linking the concept of the core and reducts:

$$
\operatorname{Core}(B)=\bigcap \operatorname{Re} d(B)
$$

Where Red (B) is the set of all reducts of B.

The significance of an attribute can be measured by comparing the degree of partial dependency $(\gamma)$ of a set, which includes the attribute with the degree of a set without the attribute. This idea can be formally described as follows:

$$
\sigma_{(C, D)}(a)=\frac{(\gamma(C, D)-\gamma(C-\{a\}, D))}{\gamma(C, D)}
$$

Where $\mathrm{a} \in \mathrm{C}$, and $\sigma(\mathrm{a})$ is the significance of attribute $\mathrm{a}(0 \leq \sigma(a) \leq 1)$. The significance of a set of attributes can be calculated in the same way as follows:

$$
\sigma(a)=\frac{(\gamma(C, D)-\gamma(C-B, D))}{\gamma(C, D)}=1-\frac{\gamma(C-B, D)}{\gamma(C, D)}
$$

Where $\mathrm{B}$ is a subset of $\mathrm{C}$. The significance of a set $\mathrm{B}$, i.e., $\sigma(\mathrm{B})$, represents the effect of eliminating the set. Thus, the set of decision attributes D will not be properly classified to the same extent as the degree of $\sigma(B)$ when taking out set $\mathrm{B}$ from $\mathrm{C}$, the set of condition attributes. Thus, we can determine an approximate reduct, the best subset for explaining a decision, by determining the significance of all possible sets. 


\subsection{Attribute reduction and Rule generation using RST}

As described earlier, a unique feature of the RST method is its generation of rules, which has great importance in the prediction of the outputs. For this purpose, the Rosetta toolkit was employed to induce rough based models. Rosetta tool lists the rules and provides some statistics for filtering the rules. Basic concepts of the RST and its supremacy for rule generation has been thoroughly discussed in the methodology review.

As described earlier, RST is used to identify the most significant features by computing subsets and cores. In order to generate reducts, Genetic Algorithm (GA) is applied as it provides a more exhaustive exploration of the search space (Wroblewski, 1995). Reducts generation has two options: full object reduction and object-related reduction. This reduction produces a set of decision rules through minimal attributes subset that distinguishes on a per-object basis, whilst reduct with full object reduction creates set of minimal attributes subset that designates functional dependencies (

In this study, a full object reduction approach is adopted. Therefore, the reducts which are used to generate rules in Economic, social and Environmental categories are [F15, F16, F18], [F12, F10, F13, F14], [F15, F16, F18] respectively. A unique feature of the RS method is its generation of rules, which is of great importance in the prediction of the outputs. For this purpose, the Rosetta system for inducing rough based models was applied. Rosetta tool lists the rules and provides some statistics for the rules which are support, accuracy, coverage, stability and length. This study adopted its definition of the rule statistics adopted from Sulaiman et al. (2008).

The number of primary decision rules generated based on produced reducts in Economic, Social and Environmental categories are $17,18,16$ respectively. To raise effectiveness, this study filters the decision rules according to the principle LHS support $\geq 2$. Using Rosetta, rules with the highest LHS Support in all sustainable groups are extracted. These rules are sorted based on LHS Support in Table 3. It is worth 
mentioning that the LHS Support indicates the number of projects satisfying the condition of the rule while the RHS Support indicates the number of projects satisfying the decision of the rule. In this study, based on the set of generated rules, the projects were classified into four categories.

Table 3. Filtered rules extracted from Rosetta software

\section{Result and Analysis}

\subsection{Explanation of proposed rough-fuzzy based model:}

This section demonstrates the development of a success prediction model using Mamdani and Takagi-Sugeno fuzzy inference expert systems. A set of the rules obtained from RST was utilised to implement the proposed DSS. The description of the proposed model is presented through two stages as shown in Fig. 1. The first step was to generate the 'if-then' rules deriving from Table 3 and define membership functions, then build the fuzzy inference engine. In order to implement this model, in the first stage, decision-makers need to give a score to inputs in each sustainability categories of economic, social and environmental. The output of this stage is success scores defuzzified to obtain crisp values. There are three output variables in the first stage, which are considered as input variables in the second stage. In the second stage, these three input variables represent the status of economic, environmental, and social success. The relative importance weightage of each category is used to obtain the sustainable success index in total. For this purpose, to design this DSS, the basic concepts of the FIS are discussed.

Fig. 1. The description of the proposed model through two stages 


\subsubsection{Fuzzy membership functions in the proposed model:}

In this study, membership functions are applied in the trapezoidal and triangular forms. A trapezoidal membership function is defined as Eq. (10). According to Eq. (10), if $b=c$ then the number is called a triangular fuzzy number.

$$
\mu_{\tilde{A}}(x)=\left\{\begin{array}{cc}
0 & x<a \\
\frac{1}{b-a}(\mathrm{x}-a) & a \leq x \leq b \\
\frac{1}{c-d}(\mathrm{x}-\mathrm{d}) & c \leq x \leq d \\
0 & x>d
\end{array}\right.
$$

In the first stage of the model, five fuzzy sets of membership functions are applied for both inputs and outputs of the FIS system. The fuzzy sets in the form of linguistic variables for inputs of stage 1 include "Very Bad", "Slightly Bad", "Moderate", "Good" and "Excellent”. These variables are equivalent to fuzzy numbers on a numeric range of $1-5$ as shown in Table 4 . As for outputs of this stage, linguistic variables are considered as "very unsuccessful", "unsuccessful”, "moderately successful”, "very successful” and "Extremely success". These variables are equivalent to fuzzy numbers on the numeric range of 0-100 (see Table 4).

\section{Table 4. The linguistic variables for inputs and outputs at the first stage}

The corresponding triangular membership functions for the inputs and outputs of stage 1 are shown in Fig. 2. The DSS in this stage is developed using Mamdani's FIS. Whereas, the FIS in the second stage is conducted based on the Takagi- Sugeno method. For the sake of simplicity, in this stage, this study only applied three fuzzy sets of membership functions for inputs of the FIS. However, a higher number of qualifiers can be used in the conceptual model to provide a better assessment. The fuzzy input sets in this 
stage are in the form of linguistic variables including "Unsuccessful", "Moderate", "Successful" which are used to evaluate the sustainable success in the second stage. The corresponding fuzzy numbers of these fuzzy sets are presented in Table 4. As shown in Table 4, linguistic variables are equivalent to fuzzy numbers on a scale of $0-100$. The corresponding trapezoidal membership function for the inputs in this stage is shown in Fig. 2. Yet, for output in this stage, the linear membership function of Sugeno-type is applied. The related fuzzy number for output of this stage is obtained using Equation (10). In the current study, the coefficients of the output membership functions of the designed FIS are obtained using AHP method. As there are three inputs in this stage, the output would be:

$y=a_{1} x_{1}+a_{2} x_{2}+a_{3} x_{3}$

where $a_{1}, a_{2}, a_{3}$ denote weights resulted from the pairwise comparison matrices of the sustainability categories detailed in Section 3.1. Finally, Fuzzy rule based-matrix in the second stage is designed as shown in Table 5.

Fig. 2. The membership functions for inputs and outputs in the first stage and outputs in the second stage

Table 5. The fuzzy rule-based matrix in the second stage

\subsubsection{Defuzzification and Calculation of the output in each stage:}

Defuzzification refers to the way in which the fuzzy number is converted into a crisp value. In this study, in the first stage, in order to calculate the project success in each sustainability categories centre of area method (COM) is used, as shown in Eq. (12) 


$$
X_{\text {COM }}=\frac{\sum_{i=1}^{n} x_{i} \cdot \mu_{i}\left(x_{i}\right)}{\sum_{i=1}^{n} \mu_{i}\left(x_{i}\right)}
$$

In Sugeno FIS, the conclusion of a fuzzy rule is constituted by a weighted linear combination of the crisp inputs rather than a fuzzy set. Besides, in this study, in the second stage, weighted average defuzzification method is used to calculate the output of DSS, which is the sustainability success index.

\section{Case Study and Model Validation}

A case study (Fig. 3) was chosen to test the validity of the model is an urban tunnel project in IranTehran, including two lines over $3993 \mathrm{~m}$ of length. The budget for the project is roughly USD\$64 million. The project commenced in 2014, and it is projected to be completed by the end of 2019. The illustrative example has been utilised for this large-scaled project (This project hereafter will be mentioned as B).

A three-member assessment team was constituted by project managers who were also the head of their departments in this project. Decision makers were asked for their perception towards status of success factors in this project as shown in Table 6. Besides, two virtual projects were defined as the extremely successful (A) and unsuccessful (C). Finally, the sustainable success index of these projects are computed applying this model.

Fig. 3. Case study details

Table 6. Decision makers' perception toward status of success factors in project B

During the implementation and result extraction, inputs' values from the data collection process are transferred to the FIS system. For visualisation of the structure of the model, the rule viewer of the second stage of the project B is shown in Fig. 4. In the rule viewer, input values can be altered by moving 
the red line, and the output can be observed along the column indicating the output variable. In the second stage of the model, there are three input variables (Economical, Social and Environmental) and three membership functions. Therefore, the rule base consisted of $27\left(3^{3}\right)$ if-then rules. To verify these rules, the inputs were increased and output was examined. Inputs and outputs were in the range of [0-100]. The output surface of the second stage of FIS for the sustainable success index on the basis of Economical and Environmental success is shown in Fig. 5. It is seen that the more the input values increase, the more output value (sustainable success index) surges. Besides, as linear Takagi-Sugeno is applied in this stage, it is seen that inputs vary linearly with the output.

The validity of the proposed model was proven by obtaining the sustainable success index of the project B, which always varies between sustainable success index of projects A and C. This model was also tested by applying different Defuzzification methods to show the validity of the model. Different approaches such as the centre of area method $(\mathrm{COM})$, the bisector of area method $(\mathrm{BOM})$, mean of the maximum method (MOM), smallest of the maximum method (SOM), and largest of the maximum method (LOM) were applied. As can be seen in Table 7, assessment results for A, B and C have the same trend in all the Defuzzification methods, and this proves the validity of this model as well. Besides, obtained final value of stage 2 (70.5) gives exactly a sustainable success index calculated using Equ.4.

Table 7. Validation of the proposed model at the first stage

Fig.4. Rule viewer of the FIS for project B

Fig. 5. The output surface of the FIS for project B 


\subsection{Prediction of Sustainable success Index based on scenario analysis}

This section addresses different scenarios for evaluating the prediction of the sustainable success index. It is assumed that each of the 27 rules in stage 2 can be considered as a potential scenario in case three numbers in each membership function range are considered as inputs. These numbers were determined 20 for unsuccessful range, 50 for moderate range and 80 for successful range. Hence the sustainable success status of projects can be predicted in these developing scenarios. For example, in the case of scenario 27, all parameter values are excellent, resulting in the highest score of 80 . By reducing the economic values to the lowest value of itself (20), the SSI score is reduced to 42.8 (scenario 9), notwithstanding other parameters are maximum. Table 8 shows these scenarios.

\section{Table 8. Prediction of SSI based on Scenario analysis}

\subsection{Sensitivity Analysis Using Fuzzy Inference System}

To evaluate the impact of each of the economic, social and environmental areas on the sustainable success index, sensitivity analysis has been performed.

For the sensitivity analysis, two areas were chosen under the identical condition and the impact of the third area on the SSI was evaluated. The results of the scenarios are presented in figure 6.

Fig.6. sensitivity analysis based on different scenarios in sustainability areas.

In this figure, the $\mathrm{X}$-axis shows the sustainability areas and the $\mathrm{Y}$-axis represents the sustainable success index. According to the figure, the equation related to each graph with a different slope shows the link between sustainability areas and the sustainable success index. There is a striking difference in the coefficients of the equations. As can be expected among the Sustainability areas, the economic area has the most impact on the sustainable success index compared to environmental and social areas.

Based on the abovementioned scenarios we compared the sustainability areas. The Bar chart (fig.7) proves the abovementioned result "special attention should be paid to the economic point of view, whilst the social and environmental aspects should be taken into account as well".

Fig.7. Sustainability areas score 


\section{Conclusion}

Infrastructure projects make a significant contribution to economic growth, social development and environmental activities, especially in developing countries, like Iran. With respect to great resource consumption and heavy investment of this kind of projects, the success of them on the basis of sustainability principles should be properly predicted before implementation as well as dynamically evaluated during the project life cycle. These measures will secure the achievement of project success. Therefore, this study was undertaken with the aim to design a DSS applying RST and FIS to predict the success of projects from the sustainability perspective.

In the present study, initially, RST was implemented for rules generation as explained in Section 3.4. The input of the rough set is a decision table, including success factors and criteria, and the output is a set of rules. Filtered rules served as the basis for the DSS. Drawing on the results and discussions, it can be inferred that rough set -fuzzy method demonstrated strong capability for evaluation and prediction of the project success. Hence, the developed model puts forward an opportunity for further improvements in achieving more sustainable success through its application.

The analysis results derived from the rough-fuzzy model suggests that economic success is the triggering fact to strengthen the social and environmental dimensions. Similarly, the social aspect needs to be taken into account as much as the environmental aspect to enhance the overall sustainable success. The result of this model can give an image of the present situation to the project managers and help them

to maintain a balance among economic, social, and environmental performance for successful implementation of construction projects throughout the project life cycle.

This research was limited to infrastructure projects with a minimum budget of around $\$ 30$ million. Hence, this model should be treated with caution if being applied for smaller size projects. Further researches should be conducted in different contexts and other countries by focusing on the particular 
infrastructure project types for comparative purposes. Moreover, as large projects have many stakeholders who have different objectives, it is recommended that the prediction of success from different stakeholders' view is studied separately. The proposed technique calls for further studies applying different approaches such as ANFIS to achieve better results in comparison with the proposed system. In this paper, the sufficiency of the rules has been somehow validated. However, it is highly recommended that potential authors repeat such prediction by implementing more rules.

\section{References}

Abd-Hamid, Z., Azizan, N. A., \& Sorooshian, S. (2015). Predictors for the Success and Survival of Entrepreneurs in the Construction Industry. International Journal of Engineering Business Management, 7.

Abidin, N. Z. (2010). Investigating the awareness and application of sustainable construction concept by Malaysian developers. Habitat International, 34(4), 421-426.

Adinyira, E., Botchway, E., \& Kwofie, T. E. (2012). Determining Critical Project Success Criteria for Public Housing Building Projects (PHBPS) in Ghana. Engineering Management Research, 1(2). doi:10.5539/emr.v1n2p122

Ahadzie, D. K., Proverbs, D. G., \& Olomolaiye, P. O. (2008). Critical success criteria for mass house building projects in developing countries. International journal of project management, 26(6), 675-687. doi:10.1016/j.ijproman.2007.09.006

Akbari, S., Khanzadi, M., \& Gholamian, M. R. (2018). Building a rough sets-based prediction model for classifying large-scale construction projects based on sustainable success index. Engineering, Construction and Architectural Management, 25(4), 534-558. doi:doi:10.1108/ECAM-05-20160110

Al-Tmeemy, S. M. H. M., Abdul-Rahman, H., \& Harun, Z. (2011). Future criteria for success of building projects in Malaysia. International journal of project management, 29(3), 337-348.

Alnaser, N., Flanagan, R., \& Alnaser, W. (2008). Model for calculating the sustainable building index (SBI) in the kingdom of Bahrain. Energy and buildings, 40(11), 2037-2043.

Aquilani, B., Silvestri, C., Ruggieri, A., \& Gatti, C. (2017). A systematic literature review on total quality management critical success factors and the identification of new avenues of research. The TQM Journal, 29(1), 184-213. doi:10.1108/tqm-01-2016-0003

Ashley, D. (1986). New trends in risk management. Paper presented at the Internet's 10th Int. Expert Seminar on 'New Approaches in Project Management', Zurich, Switzerland.

Atkinson, R. (1999). Project management: cost, time and quality, two best guesses and a phenomenon, its time to accept other success criteria. International journal of project management, 17(6), 337342.

Bakar, A., Hassan, A., Abd Razak, A., Abdullah, S., \& Awang, A. (2009). Project management success factors for sustainable housing: a framework.

Banihashemi, S., Hosseini, M. R., Golizadeh, H., \& Sankaran, S. (2017). Critical success factors (CSFs) for integration of sustainability into construction project management practices in developing countries. International journal of project management, 35(6), 1103-1119. 
Belassi, W., \& Tukel, O. I. (1996). A new framework for determining critical success/failure factors in projects. International journal of project management, 14(3), 141-151.

Belout, A., \& Gauvreau, C. (2004). Factors influencing project success: the impact of human resource management. International journal of project management, 22(1), 1-11.

Bennett, M., James, P., \& Klinkers, L. (1999). Sustainable measures: evaluation and reporting of environmental and social performance: Greenleaf Publishing.

Bourdeau, L. (1999). Sustainable development and the future of construction: a comparison of visions from various countries. Building Research \& Information, 27(6), 354-366.

Brundtland, G., Khalid, M., Agnelli, S., Al-Athel, S., Chidzero, B., Fadika, L., Hauff, V., Lang, I., Shijun, M., \& de Botero, M. M. (1987). Our common future (''brundtland reportl').

Chan, A. P., \& Chan, A. P. (2004). Key performance indicators for measuring construction success. Benchmarking: an international journal, 11(2), 203-221.

Chen, Y., Okudan, G. E., \& Riley, D. R. (2010). Sustainable performance criteria for construction method selection in concrete buildings. Automation in Construction, 19(2), 235-244. doi:10.1016/j.autcon.2009.10.004

Chen, Z., Li, H., Ross, A., Khalfan, M. M., \& Kong, S. C. (2008). Knowledge-driven ANP approach to vendors evaluation for sustainable construction. Journal of construction engineering and management, 134(12), 928-941.

Cheng, M.-Y., Huang, C.-C., \& Roy, A. F. V. (2013). Predicting project success in construction using an evolutionary Gaussian process inference model. Journal of Civil Engineering and Management, 19(sup1), S202-S211.

Cheng, M.-Y., Wu, Y.-W., \& Wu, C.-F. (2010). Project success prediction using an evolutionary support vector machine inference model. Automation in Construction, 19(3), 302-307. doi:10.1016/j.autcon.2009.12.003

Chileshe, N., \& John Kikwasi, G. (2014). Critical success factors for implementation of risk assessment and management practices within the Tanzanian construction industry. Engineering, Construction and Architectural Management, 21(3), 291-319.

Cooke-Davies, T. (2002). The "real" success factors on projects. International journal of project management, 20(3), 185-190.

Cox, R. F., Issa, R. R., \& Ahrens, D. (2003). Management's perception of key performance indicators for construction. Journal of construction engineering and management, 129(2), 142-151.

Cserhati, G., \& Szabo, L. (2014). The relationship between success criteria and success factors in organisational event projects. International journal of project management, 32(4), 613-624.

Ding, G., \& Banihashemi, S. (2017). Ecological and Carbon Footprints-The Future for City Sustainability. In Encyclopedia of Sustainable Technologies (pp. 43-51): Elsevier.

Du Plessis, C. (2007). A strategic framework for sustainable construction in developing countries. Construction Management and Economics, 25(1), 67-76.

Elattar, S. M. S. (2009). Towards developing an improved methodology for evaluating performance and achieving success in construction projects. Scientific Research and Essays, 4(6), 549-554.

Elbarkouky, M. M. (2012a). A Multi-Criteria Prioritization Framework (MCPF) to Assess Infrastructure Sustainability Objectives and Prioritize Damaged Infrastructure Assets in Developing Countries. Journal of Sustainable Development, 5(9), 1.

Elbarkouky, M. M. G. (2012b). A Multi-Criteria Prioritization Framework (MCPF) to Assess Infrastructure Sustainability Objectives. Journal of Sustainable Development, 5(9). doi:10.5539/jsd.v5n9p1 
Fernández-Sánchez, G., \& Rodríguez-López, F. (2010). A methodology to identify sustainability indicators in construction project management-Application to infrastructure projects in Spain. Ecological Indicators, 10(6), 1193-1201. doi:10.1016/j.ecolind.2010.04.009

Frödell, M., Josephson, P.-E., \& Lindahl, G. (2008). Swedish construction clients' views on project success and measuring performance. Journal of Engineering, Design and Technology, 6(1), 2132.

Huang, R.-Y., \& Hsu, W.-T. (2011). Framework development for state-level appraisal indicators of sustainable construction. Civil Engineering and Environmental Systems, 28(2), 143-164.

Ihuah, P. W., Kakulu, I. I., \& Eaton, D. (2014). A review of Critical Project Management Success Factors (CPMSF) for sustainable social housing in Nigeria. International Journal of Sustainable Built Environment, 3(1), 62-71. doi:10.1016/j.ijsbe.2014.08.001

Khang, D. B., \& Moe, T. L. (2008). Success criteria and factors for international development projects: A life-cycle-based framework. Project Management Journal, 39(1), 72-84. doi:10.1002/pmj.20034

Khosravi, S., \& Afshari, H. (2011). A success measurement model for construction projects. Paper presented at the International Conference on Financial Management and Economics IPEDR.

Kibert, C. J. (2016). Sustainable construction: green building design and delivery: John Wiley \& Sons.

Kim, D. Y., Han, S. H., Kim, H., \& Park, H. (2009). Structuring the prediction model of project performance for international construction projects: A comparative analysis. Expert Systems with Applications, 36(2), 1961-1971.

Kolo, S. J., Rahimian, F. P., \& Goulding, J. S. (2014). Offsite Manufacturing Construction: A Big Opportunity for Housing Delivery in Nigeria. Procedia Engineering, 85, 319-327. doi:https://doi.org/10.1016/j.proeng.2014.10.557

Krajangsri, T., \& Pongpeng, J. (2016). Effect of Sustainable Infrastructure Assessments on Construction Project Success Using Structural Equation Modeling. Journal of Management in Engineering, 04016056.

Lai, I. K. W., \& Lam, F. K. S. (2010). Perception of various performance criteria by stakeholders in the construction sector in Hong Kong. Construction Management and Economics, 28(4), 377-391. doi:10.1080/01446190903521515

Lam, K. C., Wang, D., Lee, P. T. K., \& Tsang, Y. T. (2007). Modelling risk allocation decision in construction contracts. International Journal of Project Management, 25(5), 485-493. doi:https://doi.org/10.1016/j.ijproman.2006.11.005

Li, B., Akintoye, A., Edwards, P. J., \& Hardcastle, C. (2005). Critical success factors for PPP/PFI projects in the UK construction industry. Construction Management and Economics, 23(5), 459471.

Liu, G., \& Yu, W. (2009). Smart case-based indexing in worsted roving process: Combination of rough set and case-based reasoning. Applied Mathematics and Computation, 214(1), 280-286.

Loosemore, M., Dainty, A., \& Lingard, H. (2003). Human resource management in construction projects: strategic and operational approaches: Taylor \& Francis.

Manoliadis, O., Tsolas, I., \& Nakou, A. (2006). Sustainable construction and drivers of change in Greece: a Delphi study. Construction Management and Economics, 24(2), 113-120.

Martínez Magaña, D., \& Fernández-Rodríguez, J. C. (2015). Artificial intelligence applied to project success: a literature review. International journal of interactive multimedia and artificial intelligence, 3(5), 77-84. 
Müller, R., \& Turner, R. (2007). The Influence of Project Managers on Project Success Criteria and Project Success by Type of Project. European Management Journal, 25(4), 298-309. doi:10.1016/j.emj.2007.06.003

Ogunlana, S. O. (2010). Beyond the 'iron triangle': Stakeholder perception of key performance indicators (KPIs) for large-scale public sector development projects. International journal of project management, 28(3), 228-236.

Park, S. H. (2009). Whole life performance assessment: critical success factors. Journal of construction engineering and management, 135(11), 1146-1161.

Pawlak, Z. (1982). Rough sets. International Journal of Computer \& Information Sciences, 11(5), 341356.

Pheng, L. S., \& Chuan, Q. T. (2006). Environmental factors and work performance of project managers in the construction industry. International journal of project management, 24(1), 24-37. doi:10.1016/j.ijproman.2005.06.001

Pheng, L. S., \& Hongbin, J. (2006). Analysing ownership, locational and internalization advantages of Chinese construction MNCs using rough sets analysis. Construction Management and Economics, 24(11), 1149-1165.

Pinto, J. K., \& Slevin, D. P. (1988). Project success: definitions and measurement techniques.

Pour Rahimian, F., Chavdarova, V., Oliver, S., \& Chamo, F. (2019). OpenBIM-Tango integrated virtual showroom for offsite manufactured production of self-build housing. Automation in Construction, 102, 1-16. doi:https://doi.org/10.1016/j.autcon.2019.02.009

Pour Rahimian, F., Seyedzadeh, S., Oliver, S., Rodriguez, S., \& Dawood, N. (2020). On-demand monitoring of construction projects through a game-like hybrid application of BIM and machine learning. Automation in Construction, 110, 103012. doi:https://doi.org/10.1016/j.autcon.2019.103012

Rockart, J. F. (1982). The changing role of the information systems executive: a critical success factors perspective: Massachusetts Institute of Technology Boston.

Ross, N., Bowen, P. A., \& Lincoln, D. (2010). Sustainable housing for low-income communities: lessons for South Africa in local and other developing world cases. Construction Management and Economics, 28(5), 433-449.

Schianetz, K., \& Kavanagh, L. (2008). Sustainability indicators for tourism destinations: A complex adaptive systems approach using systemic indicator systems. Journal of Sustainable Tourism, 16(6), 601-628.

Seyedzadeh, S., Pour Rahimian, F., Rastogi, P., \& Glesk, I. (2019). Tuning machine learning models for prediction of building energy loads. Sustainable Cities and Society, 47, 101484. doi:https://doi.org/10.1016/j.scs.2019.101484

Seyedzadeh, S., Rahimian, F. P., Glesk, I., \& Roper, M. J. V. i. E. (2018). Machine learning for estimation of building energy consumption and performance: a review. 6(1), 5. doi:10.1186/s40327-018-0064-7

Shane, J. S., Bogu, S. M., \& Molenaar, K. R. (2013). Municipal Water/Wastewater Project Delivery Performance Comparison. Journal of Management in Engineering, 29(3). doi:10.1061/(asce)me.1943-5479

Shen, L., Wu, Y., \& Zhang, X. (2010). Key assessment indicators for the sustainability of infrastructure projects. Journal of construction engineering and management, 137(6), 441-451.

Shi, H., \& Li, W. (2008, 20-22 Dec. 2008). The Integrated Methodology of Rough Set Theory and Artificial Neural-Network for Construction Project Cost Prediction. Paper presented at the 2008 Second International Symposium on Intelligent Information Technology Application. 
Skibniewski, M. J., \& Ghosh, S. (2009). Determination of key performance indicators with enterprise resource planning systems in engineering construction firms. Journal of construction engineering and management, 135(10), 965-978.

Sulaiman, S., Shamsuddin, S. M., \& Abraham, A. (2008). An implementation of rough set in optimizing mobile Web caching performance. Paper presented at the Computer Modeling and Simulation, 2008. UKSIM 2008. Tenth International Conference on.

Wang, Y.-R., Yu, C.-Y., \& Chan, H.-H. (2012). Predicting construction cost and schedule success using artificial neural networks ensemble and support vector machines classification models. International journal of project management, 30(4), 470-478. doi:10.1016/j.ijproman.2011.09.002

Westerveld, E. (2003). The Project Excellence Model@: linking success criteria and critical success factors. International journal of project management, 21(6), 411-418.

Wroblewski, J. (1995). Finding minimal reducts using genetic algorithms. Paper presented at the Proccedings of the second annual join conference on infromation science.

Yang, L.-R., Huang, C.-F., \& Wu, K.-S. (2011). The association among project manager's leadership style, teamwork and project success. International journal of project management, 29(3), 258267. doi:10.1016/j.ijproman.2010.03.006

Yeung, J. F. Y., Chan, A. P. C., Chan, D. W. M., \& Li, L. K. (2007). Development of a partnering performance index (PPI) for construction projects in Hong Kong: a Delphi study. Construction Management and Economics, 25(12), 1219-1237. doi:10.1080/01446190701598673

Yuan, J., Wang, C., Skibniewski, M. J., \& Li, Q. (2011). Developing key performance indicators for public-private partnership projects: Questionnaire survey and analysis. Journal of Management in Engineering, 28(3), 252-264.

Zarghami, E., Azemati, H., Fatourehchi, D., \& Karamloo, M. (2018). Customizing well-known sustainability assessment tools for Iranian residential buildings using Fuzzy Analytic Hierarchy Process. Building and Environment, 128, 107-128. 
Figures

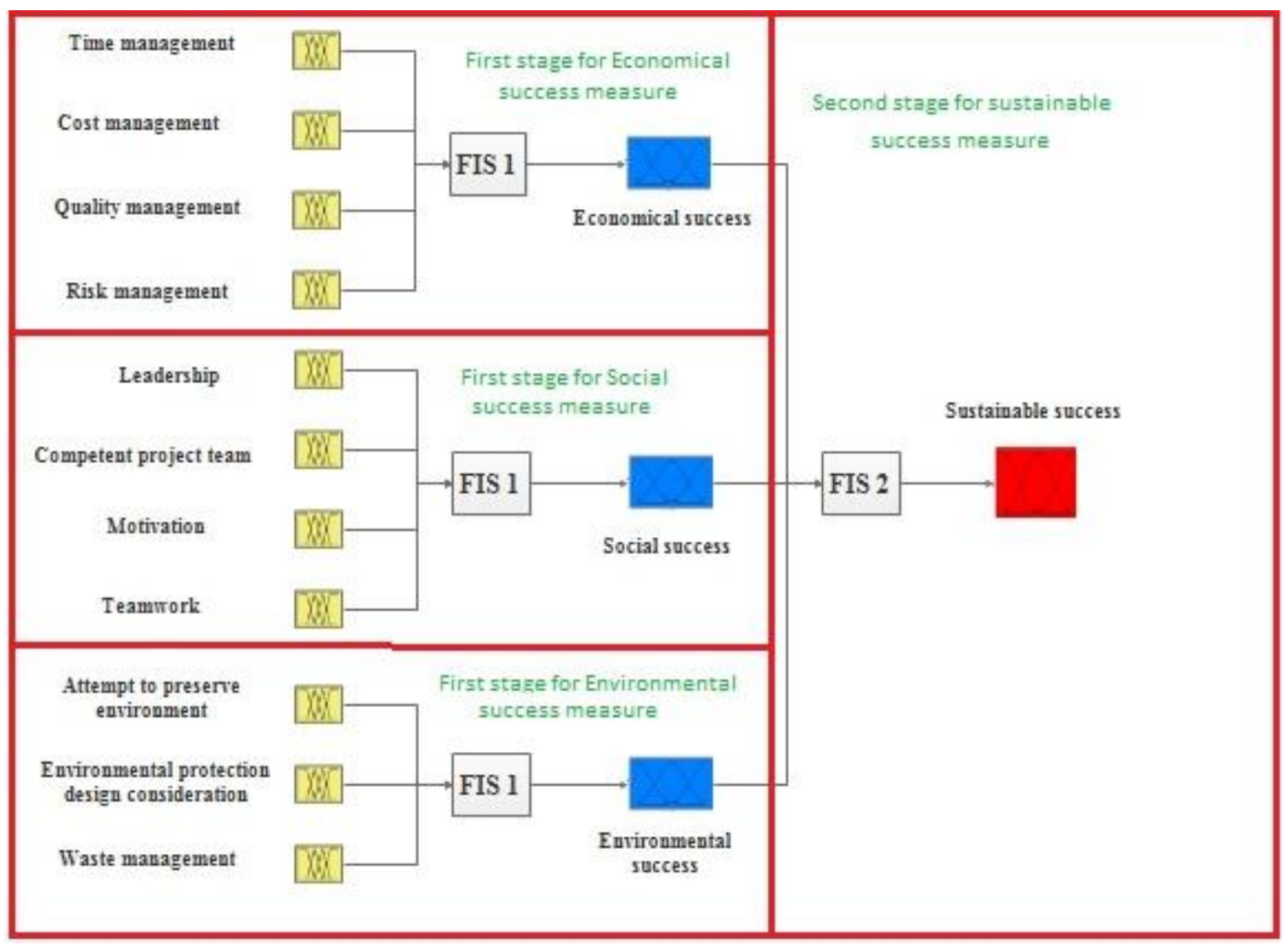

Fig.1. The description of proposed model through two stages 

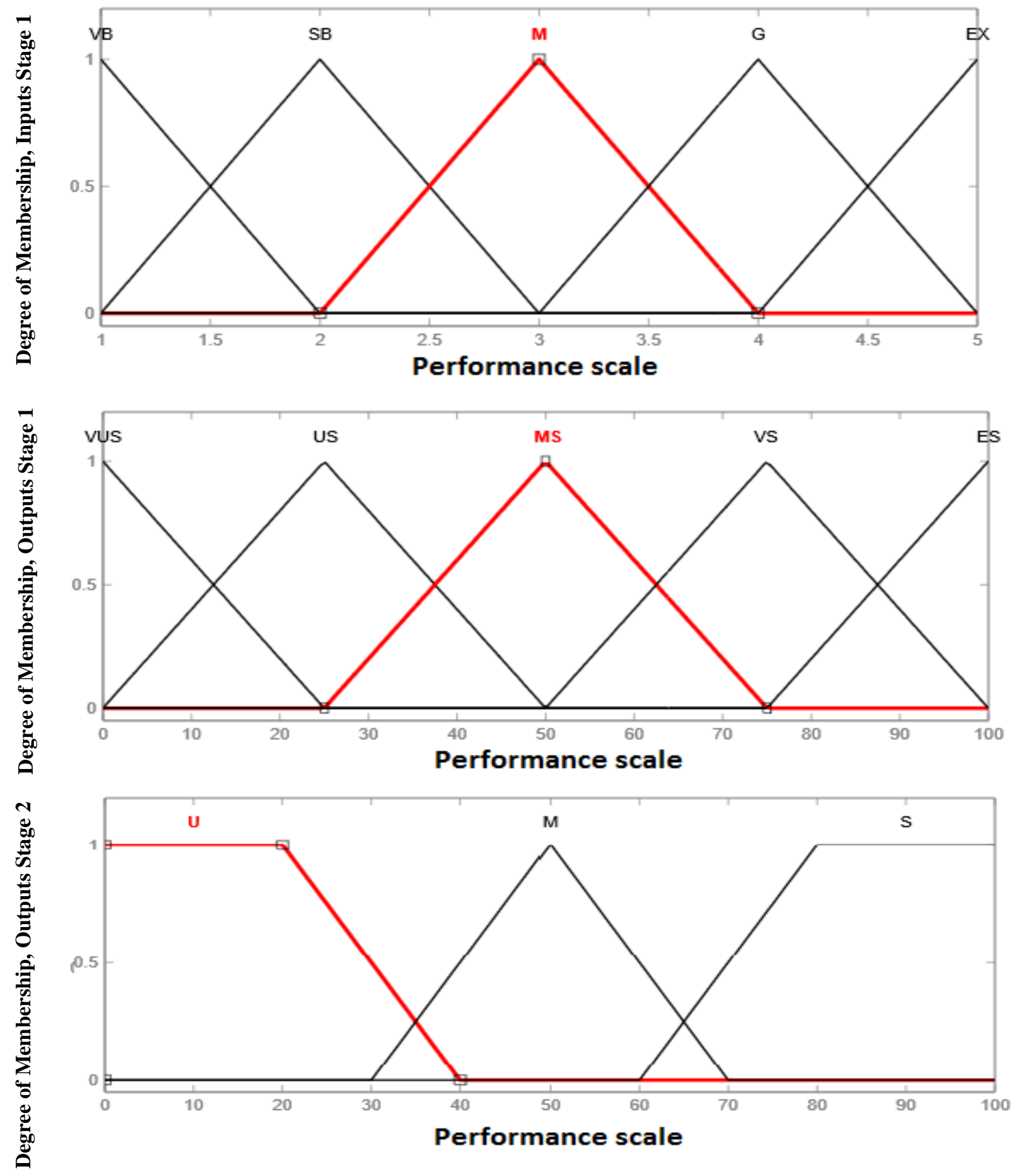

Fig. 2. The membership functions for inputs and outputs in the first stage and outputs in the second stage 


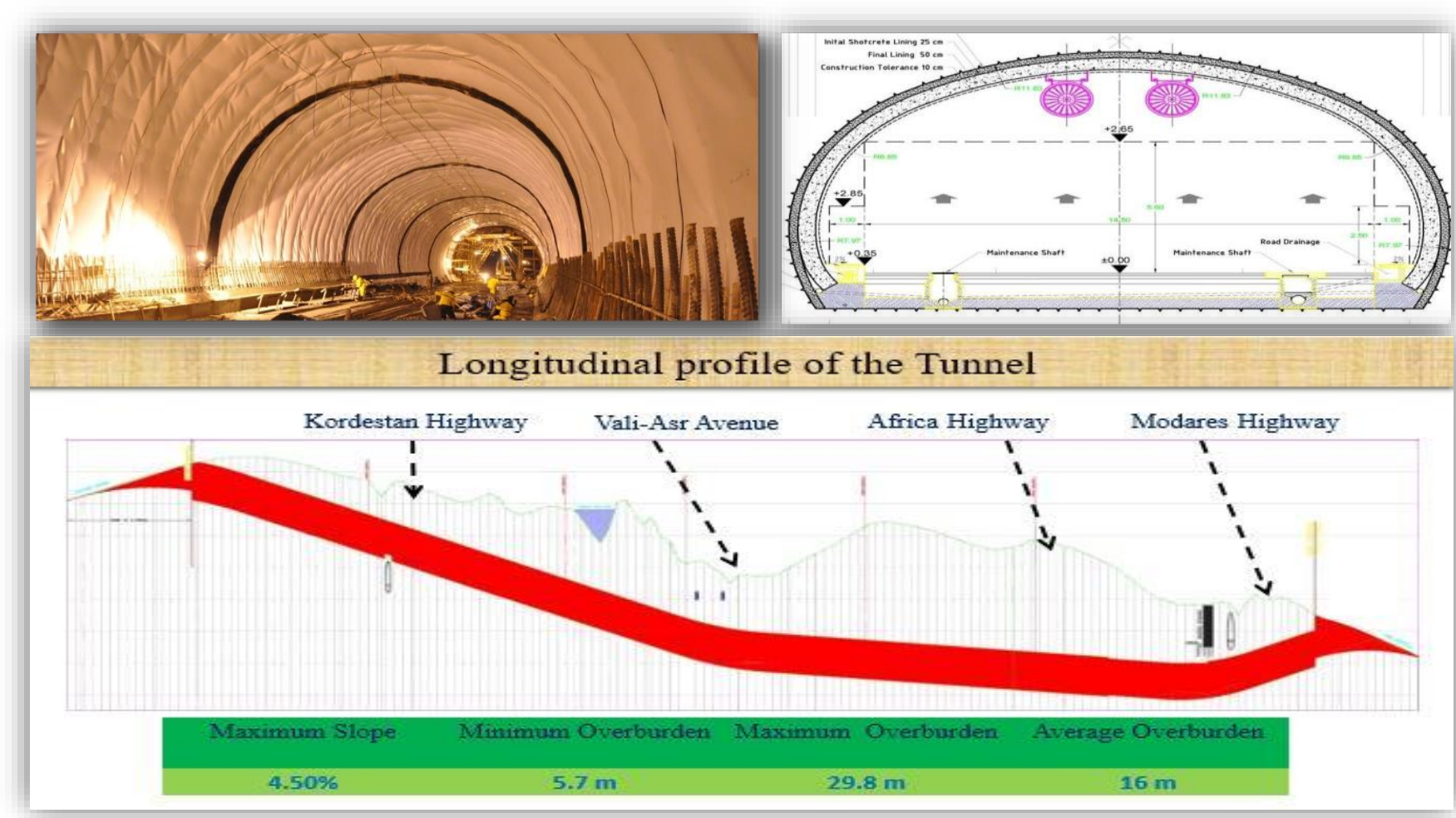

Fig. 3. Case study details 

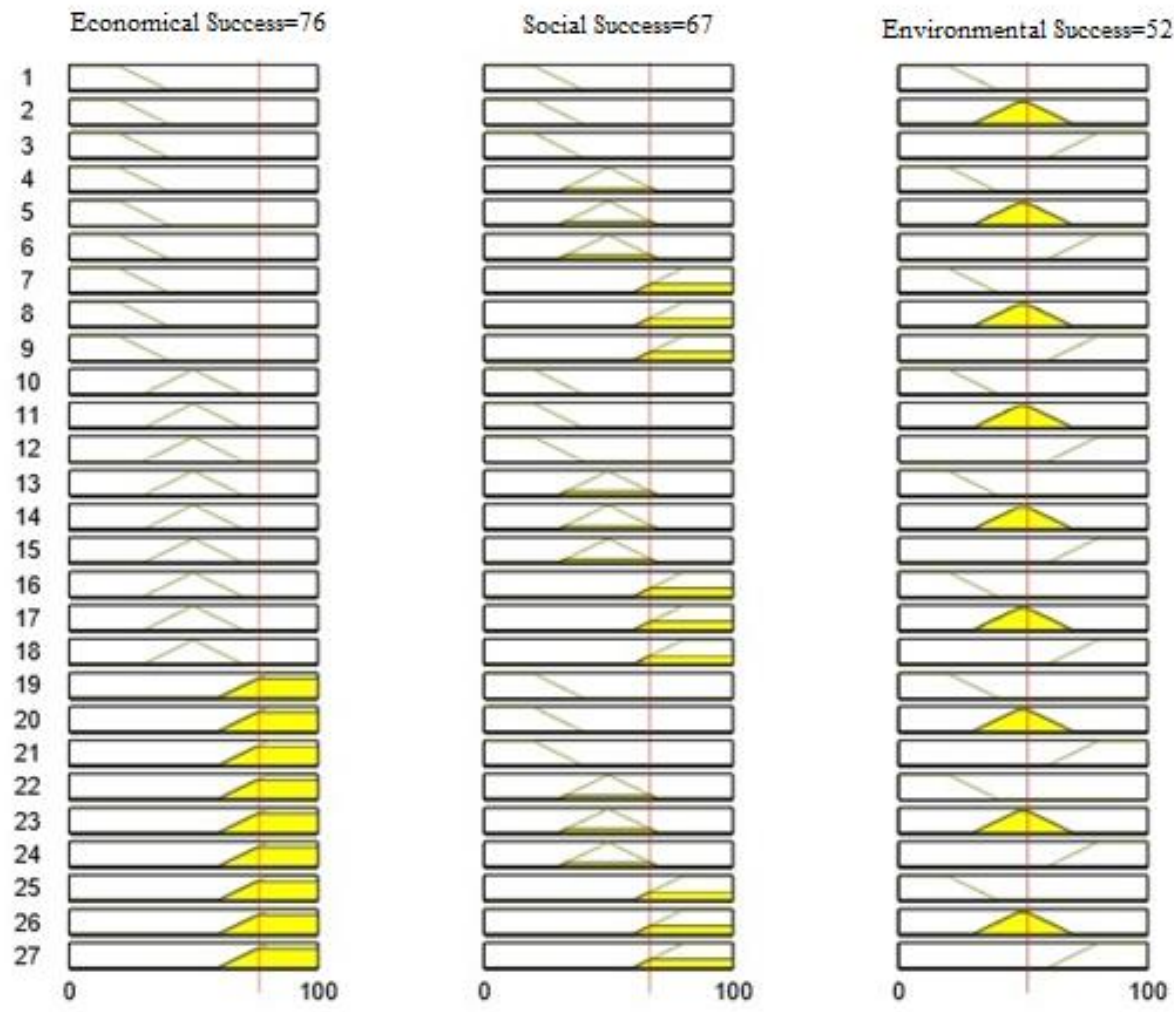

Sustainable success $=70.5$

Fig. 4. Rule viewer of the FIS for the project $B$

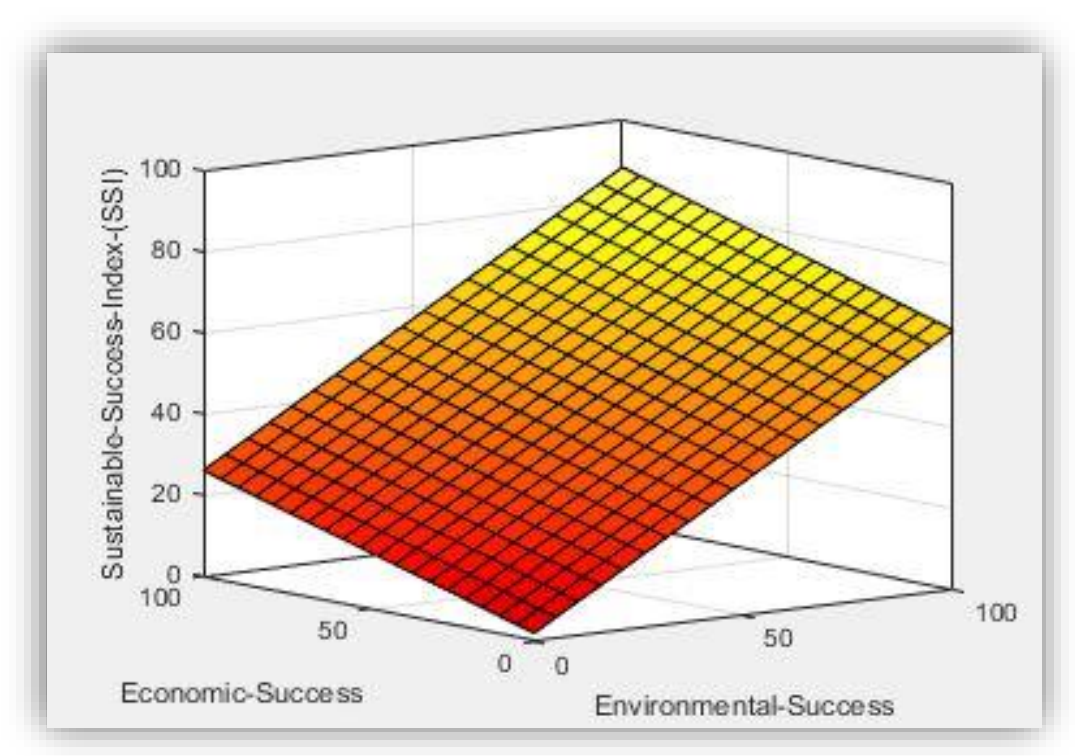

Fig. 5. The output surface of the FIS for the project B 


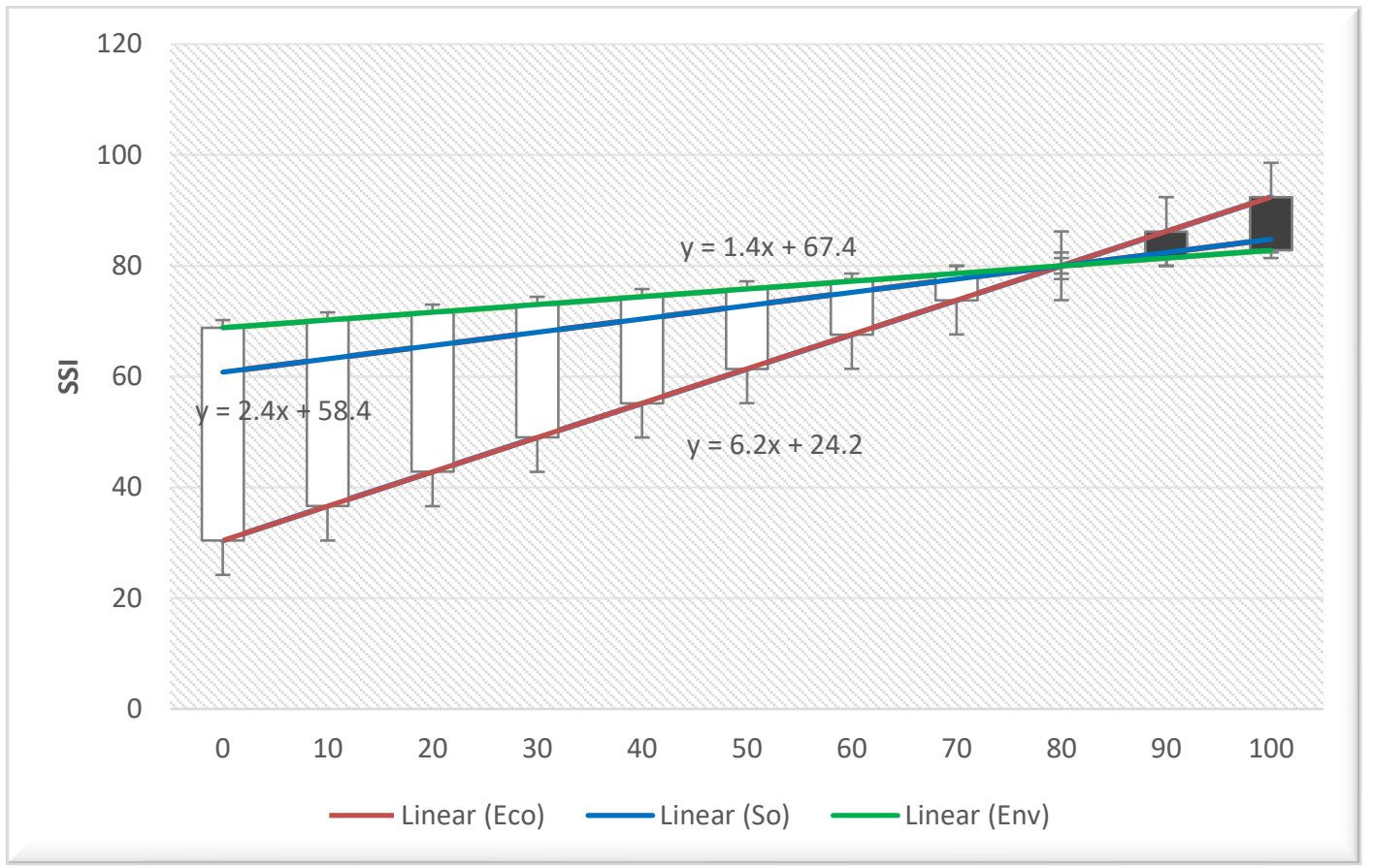

Fig.6. sensitivity analysis based on different scenarios in sustainability areas.

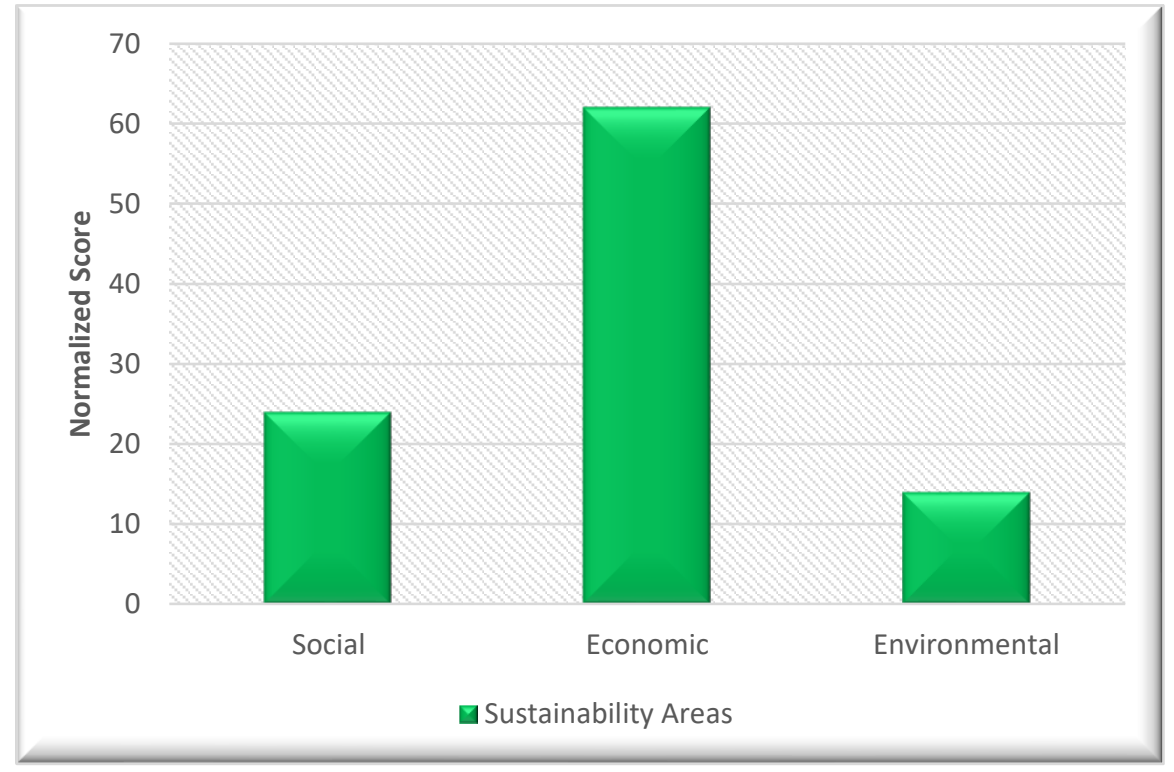

Fig.7. Sustainability areas score 


\section{Tables}

Table 3 Summary of available previous studies on sustainable success factors

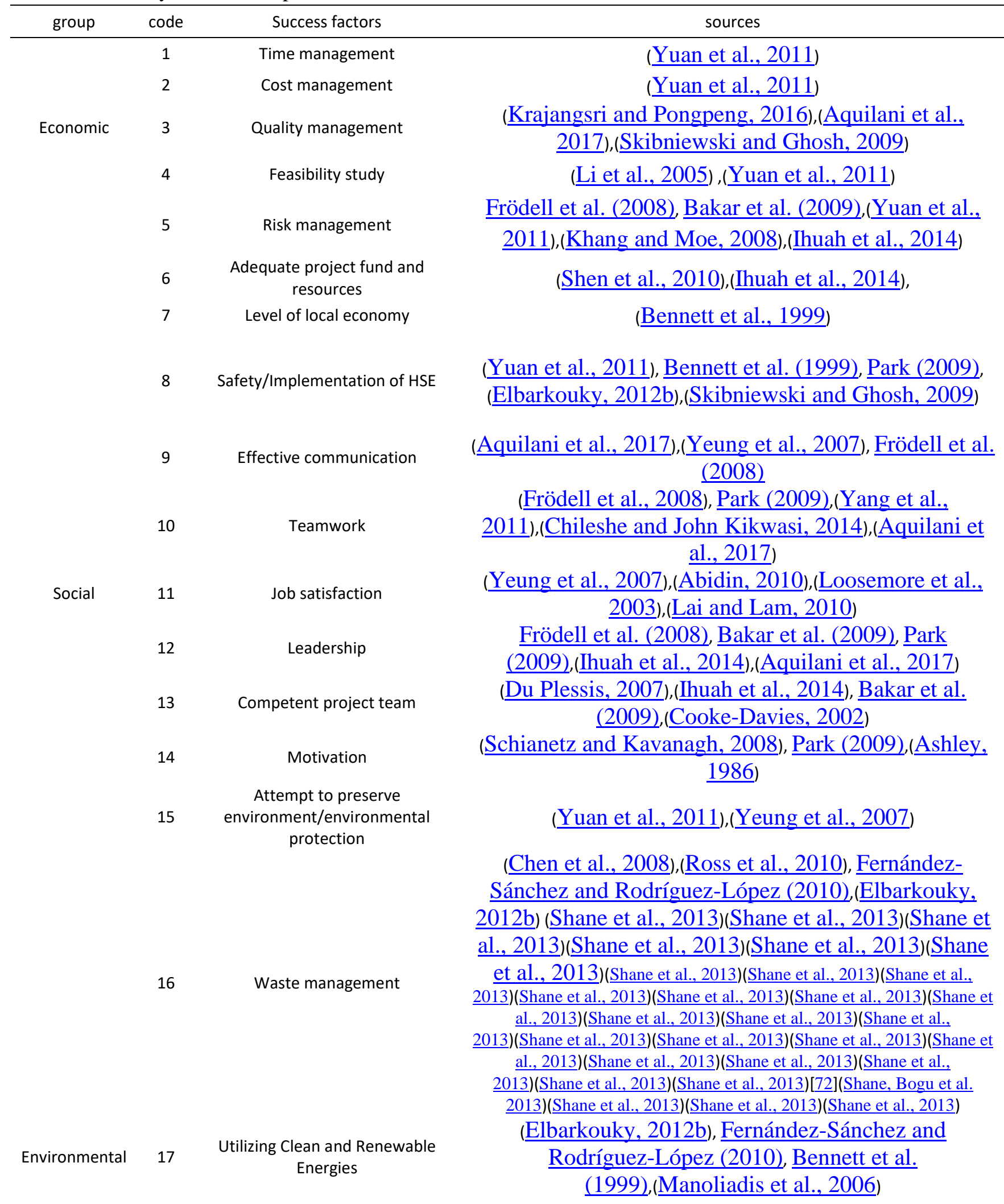


18

19

20
Environment protection measures in project design Cleaning up Contaminated Water and Land

Using Clean Technologies and

Materials
(Shen et al., 2010),(Chen et al., 2008)

(Bourdeau, 1999),(Huang and Hsu, 2011)

(Bennett et al., 1999), (Chen et al., 2008), (Ross et al., 2010) 
Table 2 Summary of available previous studies on sustainable success criteria

\begin{tabular}{|c|c|c|c|}
\hline group & code & Success criteria & sources \\
\hline \multirow{3}{*}{ Economical } & 1 & Project completion within time & $\begin{array}{c}\text { (Adinyira et al., 2012) }) \text { (Atkinson, } \\
\text { 1999),(Elattar, 2009),(吕adzie et al., 2008) }\end{array}$ \\
\hline & 2 & Project completion within budget & $\begin{array}{c}\text { (Adinyira et al., 2012) }) \text { (Atkinson, } \\
\text { 1999),(Elattar, 2009),(吕adzie et al., 2008) }\end{array}$ \\
\hline & 3 & Project quality & $\begin{array}{c}\text { (Adinyira et al., 2012), (Atkinson, } \\
\text { 1999),(Elattar, 2009),(Ahadzie et al., 2008) }\end{array}$ \\
\hline \multirow{9}{*}{ Social } & 4 & $\begin{array}{c}\text { Internal return ratio (IRR)/Return on } \\
\text { investment }\end{array}$ & (Elattar, 2009),(Shen et al., 2010) \\
\hline & 5 & $\begin{array}{l}\text { Respond to project risks/Overall } \\
\text { risk containment }\end{array}$ & (Adinyira et al., 2012),(Ahadzie et al., 2008) \\
\hline & 6 & $\begin{array}{l}\text { Employer satisfaction/Client } \\
\text { satisfaction/owner satisfaction }\end{array}$ & 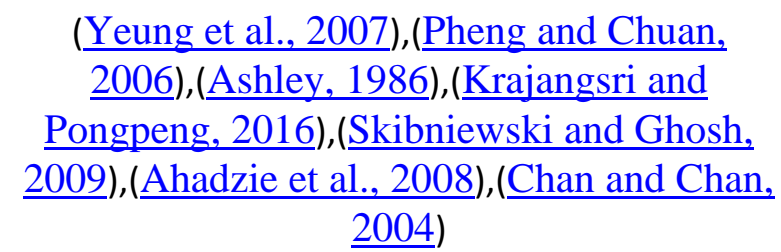 \\
\hline & 7 & $\begin{array}{c}\text { Satisfaction of people in project } \\
\text { neighbourhood/ End user } \\
\text { satisfaction/ Customer's satisfaction }\end{array}$ & 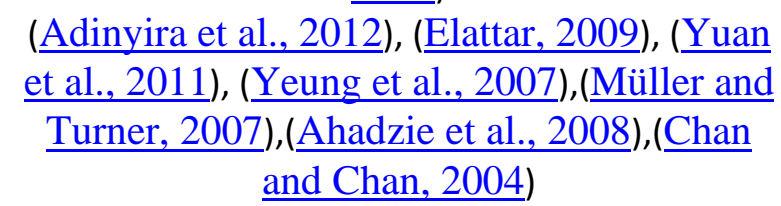 \\
\hline & 8 & $\begin{array}{l}\text { Provision of employment } \\
\text { opportunities }\end{array}$ & 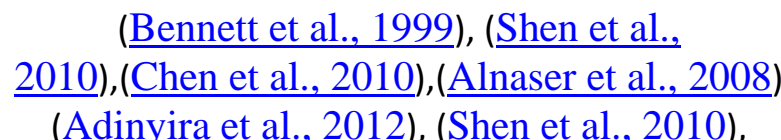 \\
\hline & 9 & $\begin{array}{l}\text { Overall health and safety } \\
\text { measures/Accident rate }\end{array}$ & $\underline{\underline{(2010)} \text {, }\left(\frac{\text { Ahadzie et al., 2008) }}{2004)},(\text { Chan and Chan, }\right.}$ \\
\hline & 10 & $\begin{array}{l}\text { Satisfaction of staffs/team } \\
\text { satisfaction }\end{array}$ & $\frac{\text { (Müller and Turner, 2007) }}{\underline{2004})},($ Chan and Chan, \\
\hline & 11 & Environmental degradation & $\frac{\text { (Adinyira et al., 2012) }}{\text { 2008),(Chan and Chan, 2004) }}$ \\
\hline & 12 & Noise pollution & $\frac{\text { (Shen et al., 2010) }}{\underline{\text { Rodríguez-López }(2010)}}$ \\
\hline \multirow{3}{*}{ Environmental } & 13 & Effect on air and land quality & (Chen et al., 2010), (Shen et al., 2010) \\
\hline & 14 & $\begin{array}{l}\text { Adverse impact on historical sites } \\
\text { and cultural heritage }\end{array}$ & $\frac{\text { (Krajangsri and Pongpeng, 2016) }}{\underline{2010} \text { ) }}$ (Shen et al., \\
\hline & 15 & Energy consumption & (Alnaser et al., 2008), Bennett et al. (1999) \\
\hline
\end{tabular}


Table 3. Filtered rules extracted from Rosetta software

\begin{tabular}{|c|c|c|c|c|c|c|c|}
\hline $\begin{array}{c}\text { Success } \\
\text { Perspective }\end{array}$ & Rule & $\begin{array}{c}\text { LHS } \\
\text { Support }\end{array}$ & $\begin{array}{c}\text { RHS } \\
\text { Support }\end{array}$ & $\begin{array}{c}\text { RHS } \\
\text { Accuracy }\end{array}$ & $\begin{array}{c}\text { LHS } \\
\text { Coverage }\end{array}$ & $\begin{array}{c}\text { RHS } \\
\text { Coverage }\end{array}$ & Class \\
\hline \multirow{8}{*}{ 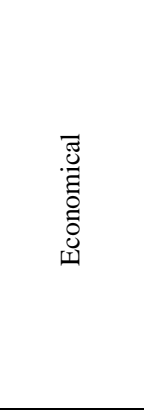 } & F1(4) AND F2(4) AND F3(4) AND F4(3) $\Rightarrow$ Economical Success(4) & 4 & 4 & 1 & 0.21 & 0.57 & 3 \\
\hline & F1(3) AND F2(3) AND F3(4) AND F4(4) $\Rightarrow$ Economical Success(3) & 3 & 3 & 1 & 0.16 & 0.50 & 2 \\
\hline & F1(3) AND F2(4) AND F3(4) AND F4(2) $\Rightarrow>$ Economical Success(4) & 2 & 2 & 1 & 0.11 & 0.29 & 3 \\
\hline & F1(1) AND F2(2) AND F3(1) AND F4(3) $\Rightarrow>$ Economical Success(2) & 2 & 2 & 1 & 0.11 & 0.50 & 1 \\
\hline & F1(2) AND F2(1) AND F3(4) AND F4(1) $\Rightarrow$ Economical Success(2) & 2 & 2 & 1 & 0.11 & 0.50 & 1 \\
\hline & F1(1) AND F2(3) AND F3(4) AND F4(2) => Economical Success(3) & 2 & 2 & 1 & 0.11 & 0.33 & 2 \\
\hline & F1(4) AND F2(5) AND F3(5) AND F4(3) $\Rightarrow>$ Economical Success(5) & 2 & 2 & 1 & 0.11 & 1.00 & 4 \\
\hline & F1(5) AND F2(3) AND F3(4) AND F4(3) => Economical Success(3) OR (4) & 2 & 1,1 & $0.5,0.5$ & 0.11 & $0.17,0.14$ & 2,3 \\
\hline \multirow{8}{*}{$\begin{array}{l}\bar{\pi} \\
\text { : } \\
\text { is }\end{array}$} & F12(4) AND F10(3) AND F13(3) AND F14(4) $\Rightarrow$ social success(3) OR (4) & 4 & 3,1 & $0.75,0.25$ & 0.22 & $0.5,0.14$ & 2,3 \\
\hline & F12(3) AND F10(4) AND F13(4) AND F14(4) $\Rightarrow$ social success(4) & 2 & 2 & 1 & 0.11 & 0.29 & 3 \\
\hline & F12(4) AND F10(5) AND F13(4) AND F14(5) $\Rightarrow>$ social success(5) & 2 & 2 & 1 & 0.11 & 1.00 & 4 \\
\hline & F12(5) AND F10(4) AND F13(3) AND F14(5) => social success(4) & 2 & 2 & 1 & 0.11 & 0.29 & 3 \\
\hline & F12(5) AND F10(4) AND F13(4) AND F14(4) => social success(4) & 2 & 2 & 1 & 0.11 & 0.29 & 3 \\
\hline & F12(2) AND F10(2) AND F13(3) AND F14(2) $=>$ social success(2) & 2 & 2 & 1 & 0.11 & 0.67 & 1 \\
\hline & F12(2) AND F10(3) AND F13(2) AND F14(4) $\Rightarrow>$ social success(2) OR (3) & 2 & 1,1 & $0.5,0.5$ & 0.11 & $0.34,0.17$ & 1,2 \\
\hline & F12(3) AND F10(2) AND F13(2) AND F14(4) $=>$ social success(3) & 2 & 2 & 1 & 0.11 & 0.33 & 2 \\
\hline \multirow{7}{*}{ 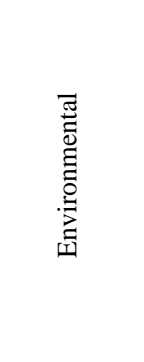 } & F15(4) AND F16(3) AND F18(2) => environmental success(4) OR (3) & 3 & 1,2 & $0.34,0.67$ & 0.16 & $0.14,0.5$ & 2,3 \\
\hline & F15(1) AND F16(1) AND F18(3) => environmental success(2) & 3 & 3 & 1 & 0.16 & 0.60 & 1 \\
\hline & F15(4) AND F16(3) AND F18(3) => environmental success(3) & 2 & 2 & 1 & 0.11 & 0.50 & 2 \\
\hline & F15(5) AND F16(4) AND F18(4) => environmental success(5) OR (4) & 5 & 3,2 & $0.6,0.4$ & 0.26 & $1.0,0.29$ & 3,4 \\
\hline & F15(4) AND F16(4) AND F18(3) => environmental success(4) & 2 & 2 & 1 & 0.11 & 0.29 & 3 \\
\hline & F15(4) AND F16(4) AND F18(5) => environmental success(4) & 2 & 2 & 1 & 0.11 & 0.29 & 3 \\
\hline & F15(3) AND F16(2) AND F18(2) => environmental success(2) & 2 & 2 & 1 & 0.11 & 0.40 & 1 \\
\hline
\end{tabular}

Table 4. The linguistic variables for inputs and outputs at first stage

\begin{tabular}{|c|c|c|c|c|c|}
\hline \multicolumn{2}{|c|}{ Inputs at first stage } & \multicolumn{2}{|l|}{ Outputs at first stage } & \multicolumn{2}{|c|}{ Inputs at second stage } \\
\hline Very Bad (VB) & $(1,1,2)$ & Very unsuccessful (VUS) & $(0,0,25)$ & Unsuccessful(U) & $(0,0,20,40)$ \\
\hline Slightly Bad (SB) & $(1,2,3)$ & Unsuccessful (US) & $(0,25,50)$ & Moderate(M) & $(30,50,50,70)$ \\
\hline Moderate(M) & $(2,3,4)$ & Moderately successful (MS) & $(25,50,75)$ & Successful(S) & $(60,80,100,100)$ \\
\hline $\operatorname{Good}(\mathrm{G})$ & $(3,4,5)$ & Very successful (VS) & $(50,75,100)$ & & \\
\hline Excellent (E) & $(4,5,5)$ & Extremely successful (ES) & $(75,100,100)$ & & \\
\hline
\end{tabular}


Table 5. Fuzzy rule-based matrix in the second stage

\begin{tabular}{cccccccc}
\hline First Input & Second Input & Third Input & Output & First Input & Second Input & Third Input & Output \\
\hline $\mathrm{U}$ & $\mathrm{U}$ & $\mathrm{U}$ & $\mathrm{U}$ & $\mathrm{M}$ & $\mathrm{M}$ & $\mathrm{S}$ & $0.86 * \mathrm{U}+0.14 * \mathrm{M}$ \\
$\mathrm{U}$ & $\mathrm{U}$ & $\mathrm{M}$ & $0.86 * \mathrm{U}+0.14 * \mathrm{M}$ & $\mathrm{M}$ & $\mathrm{S}$ & $\mathrm{U}$ & $0.62 * \mathrm{U}+0.24 * \mathrm{M}+0.14 * \mathrm{~S}$ \\
$\mathrm{U}$ & $\mathrm{U}$ & $\mathrm{S}$ & $0.86 * \mathrm{U}+0.14 * \mathrm{~S}$ & $\mathrm{M}$ & $\mathrm{S}$ & $\mathrm{M}$ & $0.74 * \mathrm{M}+0.24 * \mathrm{~S}$ \\
$\mathrm{U}$ & $\mathrm{M}$ & $\mathrm{U}$ & $0.76 * \mathrm{U}+0.24 * \mathrm{M}$ & $\mathrm{M}$ & $\mathrm{S}$ & $\mathrm{S}$ & $0.62 * \mathrm{M}+038 * \mathrm{~S}$ \\
$\mathrm{U}$ & $\mathrm{M}$ & $\mathrm{M}$ & $0.62 * \mathrm{U}+0.38 * \mathrm{M}$ & $\mathrm{S}$ & $\mathrm{U}$ & $\mathrm{U}$ & $0.62 * \mathrm{~S}+0.38 * \mathrm{U}$ \\
$\mathrm{U}$ & $\mathrm{M}$ & $\mathrm{S}$ & $0.62 * \mathrm{U}+0.24 * \mathrm{M}+0.14 * \mathrm{~S}$ & $\mathrm{~S}$ & $\mathrm{U}$ & $\mathrm{M}$ & $0.62 * \mathrm{U}+0.24 * \mathrm{M}+0.14 * \mathrm{~S}$ \\
$\mathrm{U}$ & $\mathrm{S}$ & $\mathrm{U}$ & $0.76 * \mathrm{U}+0.24 * \mathrm{~S}$ & $\mathrm{~S}$ & $\mathrm{U}$ & $\mathrm{S}$ & $0.76 * \mathrm{~S}+0.24 * \mathrm{U}$ \\
$\mathrm{U}$ & $\mathrm{S}$ & $\mathrm{M}$ & $0.62 * \mathrm{U}+0.24 * \mathrm{M}+0.14 * \mathrm{~S}$ & $\mathrm{~S}$ & $\mathrm{M}$ & $\mathrm{U}$ & $0.62 * \mathrm{U}+0.24 * \mathrm{M}+0.14 * \mathrm{~S}$ \\
$\mathrm{U}$ & $\mathrm{S}$ & $\mathrm{S}$ & $0.62 * \mathrm{U}+0.38 * \mathrm{~S}$ & $\mathrm{~S}$ & $\mathrm{M}$ & $\mathrm{M}$ & $0.62 * \mathrm{~S}+0.38 * \mathrm{M}$ \\
$\mathrm{M}$ & $\mathrm{U}$ & $\mathrm{U}$ & $0.62 * \mathrm{M}+0.38 * \mathrm{U}$ & $\mathrm{S}$ & $\mathrm{M}$ & $\mathrm{S}$ & $0.76 * \mathrm{~S}+0.24 * \mathrm{M}$ \\
$\mathrm{M}$ & $\mathrm{U}$ & $\mathrm{M}$ & $0.76 * \mathrm{M}+0.24 * \mathrm{U}$ & $\mathrm{S}$ & $\mathrm{S}$ & $\mathrm{U}$ & $0.86 * \mathrm{~S}+0.14 * \mathrm{U}$ \\
$\mathrm{M}$ & $\mathrm{U}$ & $\mathrm{S}$ & $0.62 * \mathrm{U}+0.24 * \mathrm{M}+0.14 * \mathrm{~S}$ & $\mathrm{~S}$ & $\mathrm{~S}$ & $\mathrm{M}$ & $0.86 * \mathrm{~S}+0.14 * \mathrm{M}$ \\
$\mathrm{M}$ & $\mathrm{M}$ & $\mathrm{U}$ & $0.86 * \mathrm{M}+0.14 * \mathrm{U}$ & $\mathrm{S}$ & $\mathrm{S}$ & $\mathrm{S}$ & $\mathrm{S}$ \\
$\mathrm{M}$ & $\mathrm{M}$ & $\mathrm{M}$ & $\mathrm{M}$ & & &
\end{tabular}


Table 6. Decision makers' perception toward status of success factors in project B

\begin{tabular}{|c|c|c|}
\hline \multirow{4}{*}{ Category } & Success Factors & $\begin{array}{c}\text { Decision Makers' } \\
\text { Perception }\end{array}$ \\
\hline \multirow{3}{*}{ Economical Perspective } & Time management & 4 \\
\cline { 2 - 3 } & Cost management & 4 \\
\cline { 2 - 3 } & Quality management & 3 \\
\hline \multirow{3}{*}{ Social Perspective } & Risk management & 2 \\
\cline { 2 - 3 } & Leadership & 4 \\
\cline { 2 - 3 } & Competent project team & 3 \\
\cline { 2 - 3 } & Teamwork & 3 \\
\hline \multirow{3}{*}{ Environmental Perspective } & Motivation & 3 \\
\cline { 2 - 3 } & Attempt to preserve environment & 3 \\
\cline { 2 - 3 } & Environment protection measures in project & 3 \\
& Waste Management & 2 \\
\hline
\end{tabular}

Table 7. Validation of proposed model at first stage

\begin{tabular}{lllllll}
\hline \multirow{2}{*}{ Project } & \multirow{2}{*}{ Output } & \multicolumn{4}{l}{ Assessment results using different defuzzification methods } \\
& & COM & MOM & SOM & LOM & BOM \\
\hline \multirow{3}{*}{ A } & Economical success score & 85 & 87.5 & 90 & 100 & 87 \\
& Social success score & 91 & 91 & 82 & 100 & 82 \\
& Environmental success score & 82 & 82 & 82 & 87 & 82 \\
\hline \multirow{3}{*}{ B } & Economical success score & 76 & 76 & 65 & 96 & 69 \\
& Social success score & 67 & 67 & 53 & 76 & 67 \\
& Environmental success score & 52 & 52 & 48 & 63 & 55 \\
\hline \multirow{2}{*}{ C } & Economical success score & 20 & 20 & 4 & 10 & 20 \\
& Social success score & 10 & 10 & 2 & 15 & 20 \\
& Environmental success score & 15 & 15 & 7 & 20 & 20 \\
\hline
\end{tabular}




\begin{tabular}{|c|c|c|c|c|}
\hline Scenario. No & Eco & So & Env & $\begin{array}{l}\text { SSI (out of 100) using } \\
\text { Trapezoidal MF }\end{array}$ \\
\hline 1 & 20 & 20 & 20 & 20 \\
\hline 2 & 20 & 20 & 50 & 24.2 \\
\hline 3 & 20 & 20 & 80 & 28.4 \\
\hline 4 & 20 & 50 & 20 & 27.2 \\
\hline 5 & 20 & 50 & 50 & 31.4 \\
\hline 6 & 20 & 50 & 80 & 35.6 \\
\hline 7 & 20 & 80 & 20 & 34.4 \\
\hline 8 & 20 & 80 & 50 & 38.6 \\
\hline 9 & 20 & 80 & 80 & 42.8 \\
\hline 10 & 50 & 20 & 20 & 38.6 \\
\hline 11 & 50 & 20 & 50 & 42.8 \\
\hline 12 & 50 & 20 & 80 & 47 \\
\hline 13 & 50 & 50 & 20 & 45.8 \\
\hline 14 & 50 & 50 & 50 & 50 \\
\hline 15 & 50 & 50 & 80 & 54.2 \\
\hline 16 & 50 & 80 & 20 & 53 \\
\hline 17 & 50 & 80 & 50 & 57.2 \\
\hline 18 & 50 & 80 & 80 & 61.4 \\
\hline 19 & 80 & 20 & 20 & 57.2 \\
\hline 20 & 80 & 20 & 50 & 61.4 \\
\hline 21 & 80 & 20 & 80 & 65.6 \\
\hline 22 & 80 & 50 & 20 & 64.4 \\
\hline 23 & 80 & 50 & 50 & 68.6 \\
\hline 24 & 80 & 50 & 80 & 72.8 \\
\hline 25 & 80 & 80 & 20 & 71.6 \\
\hline 26 & 80 & 80 & 50 & 75.8 \\
\hline 27 & 80 & 80 & 80 & 80 \\
\hline
\end{tabular}

